\title{
Volumetric variations of Glacier de Sarennes, French Alps, during the last two centuries
}

\author{
François Valla, Ghristian Piedallu \\ Division Nivologie, CEMAGREF, Campus universitaire - Grenoble, BP 76, 38402 Saint-Martin-d'Hères, France
}

\begin{abstract}
Glacier de Sarennes, located in the heart of the French Alps, has been observed closely since 1906 and regularly measured (snow accumulation, ablation and mass balance) since 1948. Several publications have stemmed from this research, such as the 1906 and 1958 glaciological maps and the 1981 and 1991 photogrammetric analyses. In 1992, a field radar campaign determined the ice thickness and allowed the drawing of the bedrock map with reasonable accuracy. The Little Ice Age stage was reconstructed with the bedrock tracks, in 1995.

The above-mentioned documents were digitized, and the computer program Arc-Info permitted the calculation of the successive volume stages occupied by the glacier from 1850 to 1991. Cross-sections and slope profiles illustrate the evolution of the thickness of Glacier de Sarennes during the last 150 years. All of these results, consistent with the variation of the mass balance observed or estimated, show the main conclusion: compared with today, the glacier was about four times more voluminous 90 years ago (i.e. it has lost three-quarters of its ice volume) and five times bigger one and a half centuries ago.
\end{abstract}

\section{CHARACTERISTICS OF GLACIER DE SARENNES}

Glacier de Sarennes $\left(45^{\circ} 7^{\prime} \mathrm{N}, 6^{\circ} 8^{\prime} \mathrm{E}\right)$ is located on the south slope of Pic du Lac Blanc (3323 m), to the east of Grenoble, near the ski resort of Alpe d'Huez (Grandes Rousses range). Its area today is about $0.5 \mathrm{~km}^{2}$ as against $1.57 \mathrm{~km}^{2}$ in 1850 (glacier tongue in 1853 situated $1.3 \mathrm{~km}$ further downstream). Its length is $1350 \mathrm{~m}$ (in 1991), the tongue is at an altitude of $2850 \mathrm{~m}$, the top at $3190 \mathrm{~m}$. The maximum width is $1000 \mathrm{~m}$, and the thickness is no more than $80-100 \mathrm{~m}$. One can observe many moulins $30-40 \mathrm{~m}$ deep, draining the meltwater at the glacier surface.

This glacier has been visited by glaciologists for more than a century. The French geologist P. Termier mentioned the name of Sarennes in 1882, and P. R. Bonaparte visited the glacier in 1891. He noted that the tongue of the glacier was stationary. The first scientific observations were conducted in 1905- 06 by Grenoble University, with the printing of an accurate map of the Grandes Rousses range (Flusin and others, 1909). Between the two world wars, only a few observations were made and photographs taken (published in 1927). In 1948, the Eaux et Forêts corps decided to take care of a summer field-data collection with winter snow accumulation and summer ablation (Garavel, 1955). This job is today continued by CEMAGREF (Valla, 1989), a scientific research organisation and offshoot of Eaux et Forêts.

In winter, this small glacier is like a huge gauge, accumulating solid precipitation measured at five representative locations marked by poles (Fig. 1). In summer, ablation is generally important, due to the south exposure, and the equilibrium line is often over $3200 \mathrm{~m}$. Mass balance is given by a linear combination of the local mass balance at each pole (coefficient proportional to the glacier area strip represented by the ablation pole). Martin (1978) reconstituted the mass balance with the meteorological data of Grenoble for the 1880-1948 period.

\section{GLACIOLOGICAL DOGUMENTS}

In this work, we used all the available glaciological data, maps and aerial photographs. For the Little Ice Age we used the terrain restitution made in 1995 with the terrain evidence. We also used the bedrock map produced by the radar ice-thickness campaign and the topographic maps from the Institut Géographique National. We digitized the isohypses of the maps and applied Arc-Info for volume calculation and determination of sections.

\section{0 stage}

Around 1850, the extension of glaciers in the Alps was at a maximum. Remote traces are still visible, such as a clear bedrock colour contrasting with the surroundings. In 1995, we made the survey and drew the map of the Little Ice Age (Piedallu, 1995). Assuming that the surface of the glacier is clearly defined, the contour lines can be drawn "realistically" or with a rather high delineation or a low one. For further analysis we chose the high delineation of contour lines.

\section{6 glaciological map}

In 1905 and 1906, scientists of Grenoble University mapped the glaciers of the Grande Rousse range at a scale of 1:10000 with remarkable accuracy. The results were published in 1909 in the first volume of Etudes Glaciologiques (Flusin and others, 1909). More than 100 points were surveyed with decimetric accuracy, and contour lines of $10 \mathrm{~m}$ equidis- 


\section{M MSSII DIS GRANDES ROUSSES}

Carte dressée en 1905 (k-17-Aoûl) el 1000 (11-21 Août) au cours des c̀mpagnes glaciologiques eflectuees par

M.M. G.TLUSTN, CH. JACOB, J.OFFNER Préparsteurs ì la Faculto des Sciences de Grenoble.

Levé tachéométrique al exécution du canevas par M.C.Lafaj, Conducteur des Ponts \& Chaussies, Restitution photographique du détail, rédaction des glaciers et figuré du terrain encaissant par M.G. Flusin.

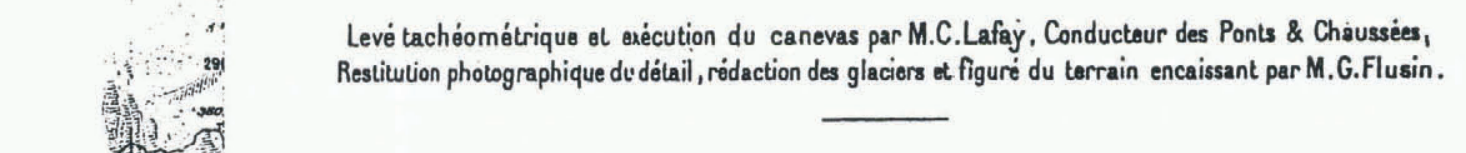


Table 1. Evolution of the main parameters, Glacier de Sarennes, 1850-1991

\begin{tabular}{cccccc}
\hline Year & Perimeter & Area & Volume & $\begin{array}{c}\text { Average } \\
\text { thickness }\end{array}$ & $\begin{array}{c}\text { Maximum } \\
\text { thickness }\end{array}$ \\
& $\mathrm{km}$ & ha & $10^{6} \mathrm{~m}^{3}$ & $\mathrm{~m}$ & $\mathrm{~m}$ \\
\hline$\approx 1850$ hd & 7.2 & 156.5 & 79 & 50 & 202 \\
$\approx 1850$ ld & 7.2 & 156.5 & 72 & 46 & 162 \\
1906 & 6.4 & 108.5 & 65 & 60 & 154 \\
1959 & 7.1 & 78 & 30 & 39 & 115 \\
1981 & 6.3 & 67 & 22 & 33 & 98 \\
1991 & 6.1 & 52.5 & 16 & 30 & 94 \\
\hline
\end{tabular}

hd, high delineation; Id, low delineation.

tance were drawn. The topographical accuracy of this map is higher than $5 \%$. Digitizing errors or positioning errors of the reference points are less than $0.5 \%$.

\section{0 glaciological map}

In 1950, a glaciological map was compiled (Cherrey, 1951), but despite a good topographic accuracy $(3 \%)$, the glacier delimitation is so inaccurate that it could not be used for this study.

\section{9 glaciological map}

This document (de Crecy, 1963) is the product of two field campaigns in 1956 and 1959. The global accuracy is rather poor (error $17.5 \%$ ) but it was possible to correct the position of the glacier on the topographic map, so we used this map for the study.

\section{1 aerial picture analysis}

Since 1970, the Division Nivologie of CEMAGREF has surveyed the main glaciers of the French Alps by means of aerial photographs taken every 3 years. The Sintegra office produced an orthophoto image and mapped the glacier

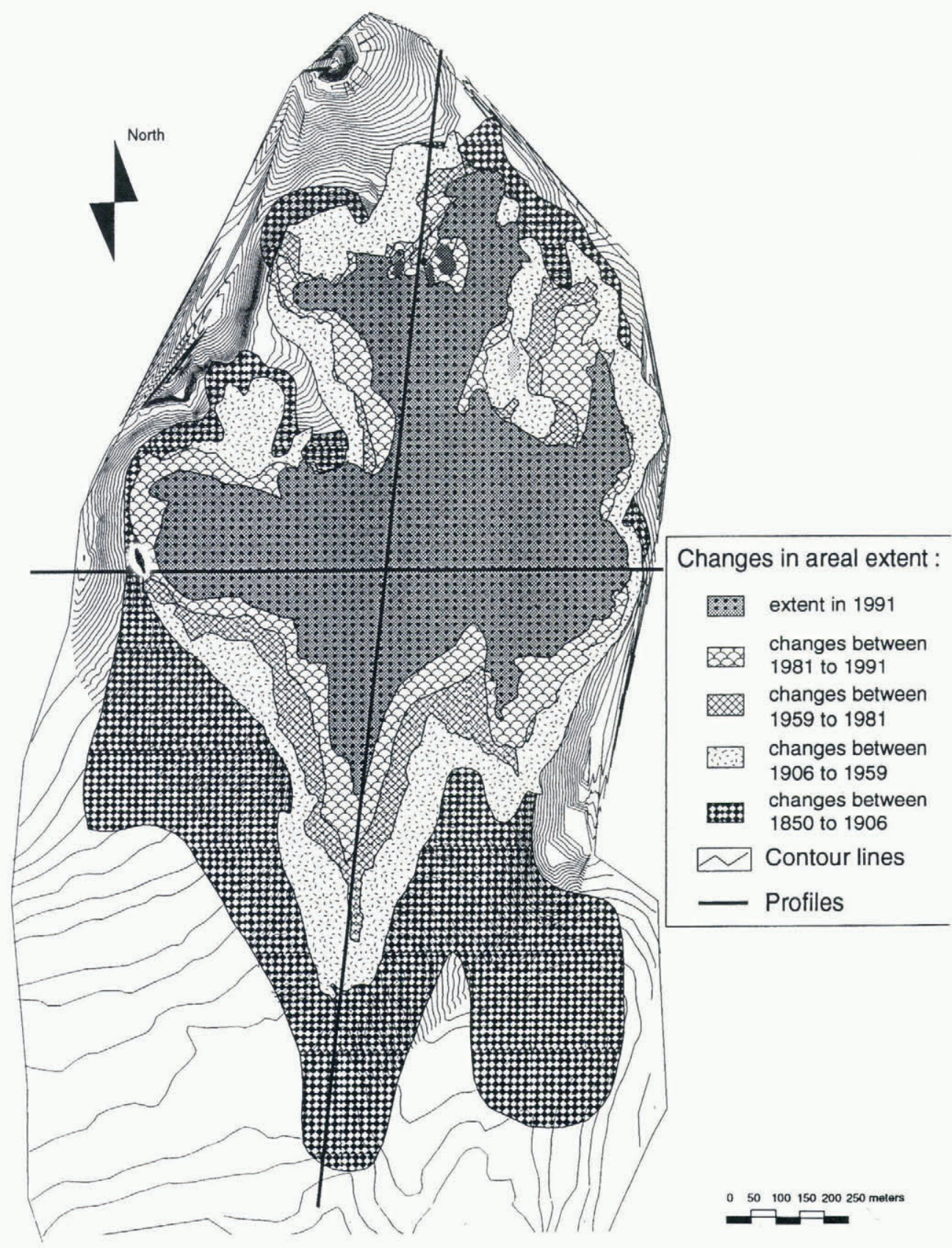



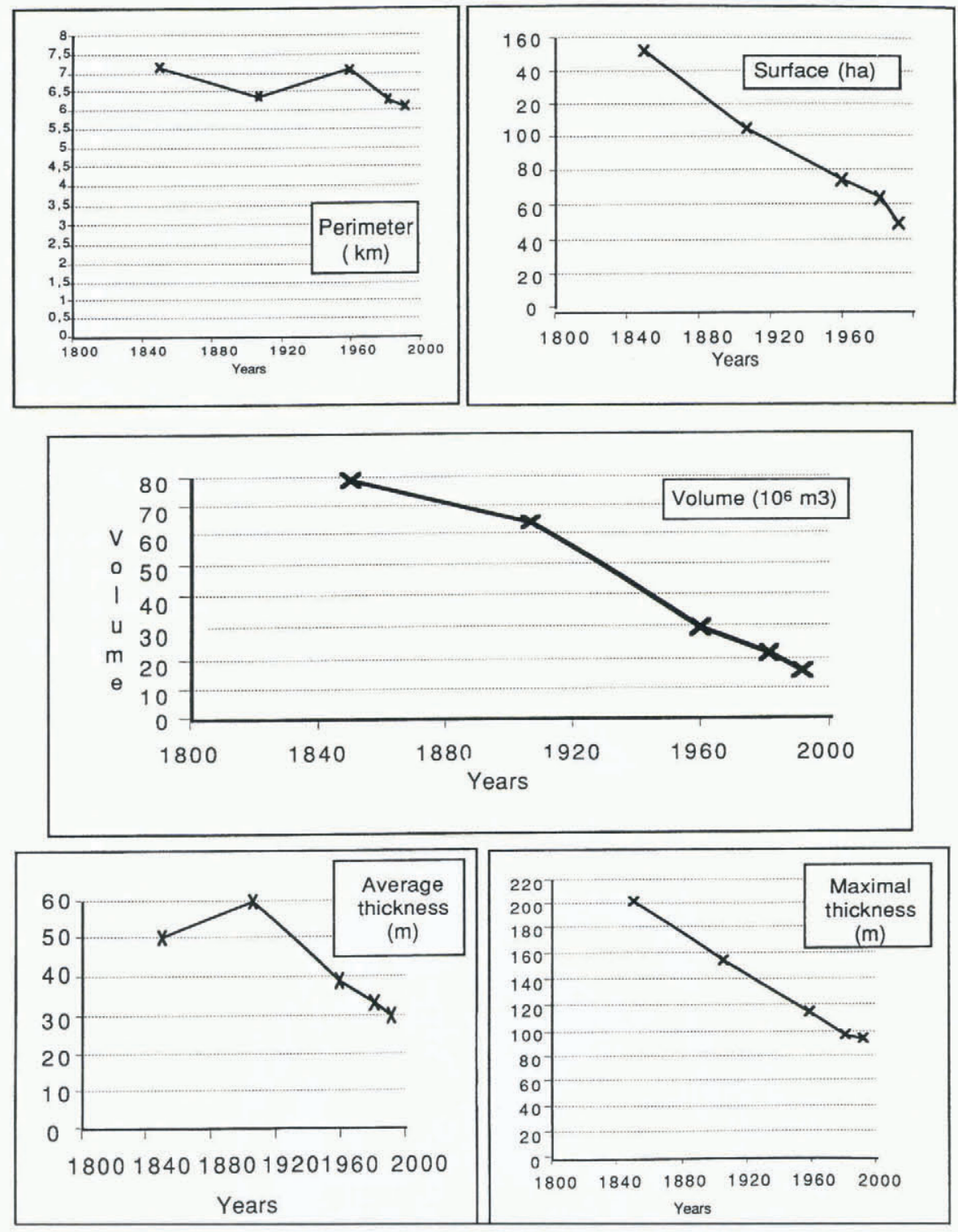

Fig. 3. Surface, perimeter, volume and thickness evolution of Glacier de Sarennes, 1850-1991.

with the 1981 photo at a scale of 1:5000 (Valla, 1982) as well as the hydrological basin defined by the gauging station at an elevation of $2700 \mathrm{~m}$. Because of a good accuracy (error $1 \%$ ), we decided to take this map as a reference for the glacier basin; but the precision of the ice boundaries was enhanced using other documents.

\section{1 aerial picture mapping}

For the newest map, we used the Sintegra 1991 aerial picture. When the photograph was taken, the glacier was completely snowless and the delineation of the ice surface clearly visible. The mapping (Girard, 1993) was done by Savoie University with a $5 \%$ precision.

\section{2 bedrock map}

In 1991, a seismic sounding campaign was conducted by the Laboratoire de Glaciologie du CNRS, Grenoble. The maximum depth of the ice was found to be around $100 \mathrm{~m}$ and it was decided to carry out a radar campaign with the EPF Zurich glaciology laboratory. As a result, over 80 ice thickness points were measured on the glacier in 1992 (Funk and others, 1993). Using the 1981 map, the bedrock map was ob- tained with an accuracy of about $10 \mathrm{~m}$, in accordance with the radar precision and the interpolation computer software.

\section{ANALYSIS OF THE GLACIOLOGICAL STAGES AND EVOLUTION}

Working with the Geographic Information System (ArcInfo) (Berger, 1992), we constructed the three-dimensional map for each stage, and extracted the main parameters with their evolution during the last two centuries (Table 1; Fig. 2). Figure 3 shows the graphical representation of these values.

Around 1850 was the stage of maximum extension, with an area of more than $1.5 \mathrm{~km}^{2}$ (156.5 ha, three times the present value) and a volume of $79 \times 10^{6} \mathrm{~m}^{3}$ (five times the 1991 value) according to the high-delineation assumption. The low delineation is less realistic, and the difference between the assumptions is $10 \%\left(7 \times 10^{6} \mathrm{~m}^{3}\right)$.

The average thickness $(50 \mathrm{~m})$ of the glacier is less than it is half a century later $(60 \mathrm{~m})$ because the surface gained during the last Little Ice Age is rather thin.

In 1906 the glacier area extent is a little more than $1 \mathrm{~km}^{2}$ (108.5 ha), and the glacier surface has been in constant re- 


\section{Changes in the longitudinal profile of glacier de Sarennes during last 150 years}
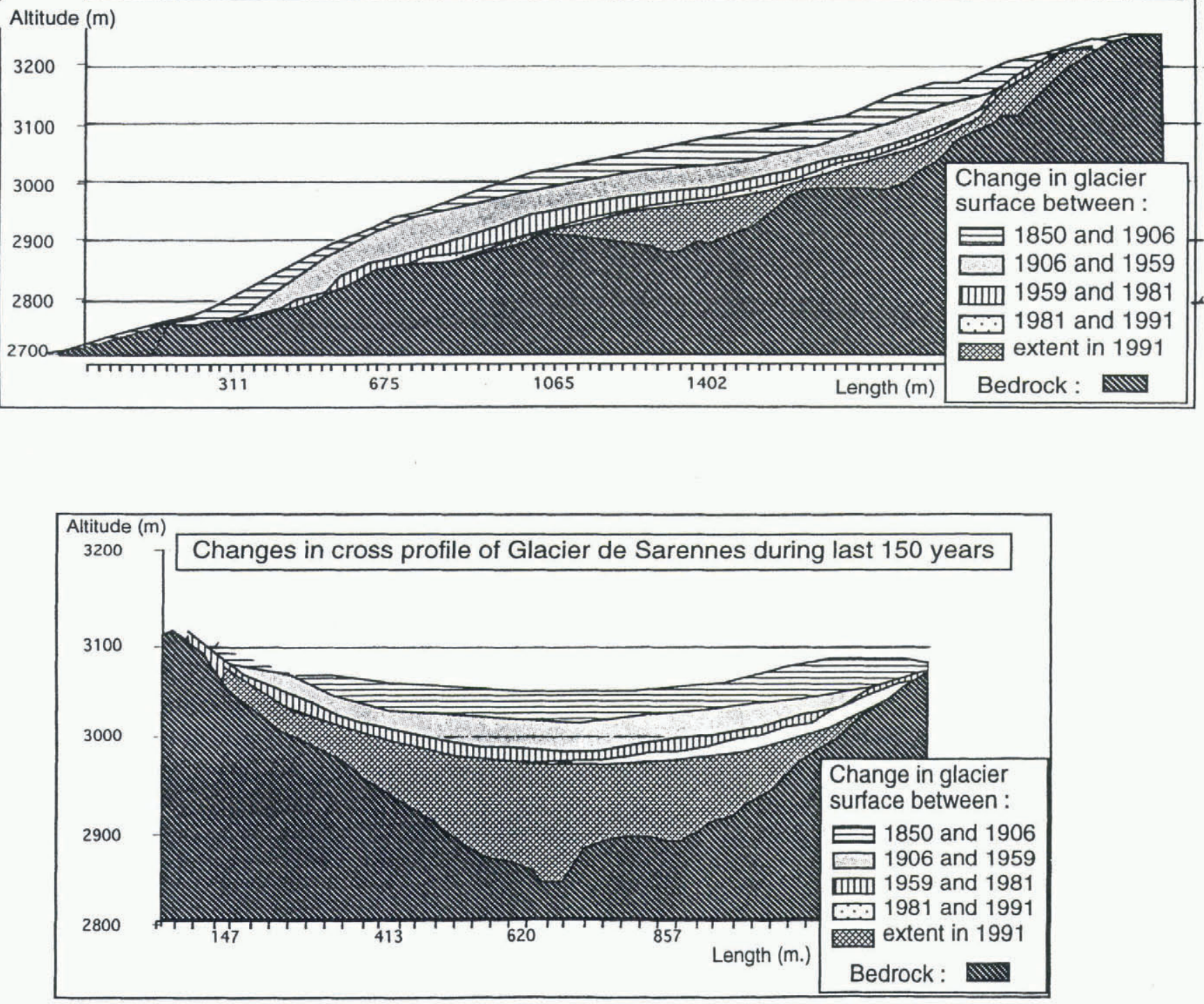

Fig. 4. Longitudinal and cross profiles visualizing Glacier de Sarennes length and thickness variations between 1850 and 1991.

treat for half a century (the front position was $900 \mathrm{~m}$ lower in 1853 than the 1906 front position). The perimeter is $6.4 \mathrm{~km}$, and we calculated a volume of $65 \times 10^{6} \mathrm{~m}^{3}$. The maximum thickness is $154 \mathrm{~m}$, just in the middle of the glacier near today's measurement location 3, and the glacier's average thickness is about $60 \mathrm{~m}, 10 \mathrm{~m}$ higher than in 1850 .

In 1959 the surface has reduced to $78 \mathrm{ha}$, whereas the perimeter, $7.1 \mathrm{~km}$, has slightly increased, as an effect of the break-up of the glacierized area. The volume is reduced, to $30 \times 10^{6} \mathrm{~m}^{3}$. The thickness at the glacier centre is about $115 \mathrm{~m}$, whereas average thickness is $39 \mathrm{~m}$.

In 1981 the glacier is even smaller, with a surface of 67 ha and a perimeter of $6.3 \mathrm{~km}$. Its volume has reduced to $22 \times 10^{6} \mathrm{~m}^{3}$, the maximum thickness is $98 \mathrm{~m}$ and the average thickness $33 \mathrm{~m}$. The shrinkage started at the end of the Little Ice Age is still active and will be accelerated for the next 15 years.

In 1991, despite 4 years of mass balance near zero, the surface is only $52.5 \mathrm{ha}$, but the perimeter is about the same, $6.1 \mathrm{~km}$. The volume continues to be reduced, at $16 \times 10^{6} \mathrm{~m}^{3}$, and the average thickness is on the order of $30 \mathrm{~m}$ (maximum thickness $94 \mathrm{~m}$ ). Since this date, drastic negative mass balances between 1991 and 1994 have amplified the shrinkage.

\section{Longitudinal and cross-sections}

Figure 4 shows the changes in the surface of Glacier de Sarennes along two profiles (Fig. 2) over the last 150 years. The longitudinal profile depicts the drastic retreat of the glacier between 1850 and 1906. The cross-section illustrates the loss of thickness, and both sections highlight the significant loss of ice: today, we can observe only one-fifth of the 1850 glacier volume! We can see the sagging of the surface especially in the centre of the glacier.

Based on the bedrock map, we can predict that frontal retreat will be rather small even with further ice loss. The glacier has quite a significant ice thickness just uphill of its actual front position. If the retreat continues, we can expect two small lakes in the centre of the cross-section in a few decades.

\section{Global melt-rate evolution}

During the studied period 1850-1991, the volume of the glacier changed quite rapidly but not regularly. The global net loss through melting is calculated for the four periods shown in Table 2 , which also gives mean annual values. 
Table 2. Net loss through melting (ice and w.e.), 1850-1991, calculated for four different periods, Glacier de Sarennes

$1850-1906 \quad 1906-59 \quad 1959-81 \quad 1981-91$

\begin{tabular}{lcccc}
\hline $\begin{array}{l}\text { Duration (years) } \\
\text { Loss in volume }\left(10^{6} \mathrm{~m}^{3}\right)\end{array}$ & 56 & 53 & 22 & 10 \\
$\begin{array}{l}\text { Mean area during the } \\
\text { period (ha) }\end{array}$ & 14 & 35 & 8 & 6 \\
$\begin{array}{l}\text { Mean annual net loss } \\
\text { through melting }\left(10^{6} \mathrm{~m}^{3}\right)\end{array}$ & 0.25 & 0.66 & 0.36 & 0.6 \\
$\begin{array}{l}\text { Mean annual ice loss } \\
\quad(\mathrm{cm} \text { year }\end{array}$
\end{tabular}

Between 1850 and 1906 the glacier lost $14 \times 10^{6} \mathrm{~m}^{3}$ in 56 years, an annual melting rate of $250000 \mathrm{~m}^{3}$ year ${ }^{-1}$. Between 1906 and 1950, this value increased to $660000 \mathrm{~m}^{3}$ year ${ }^{-1}$; for the period 1959-81, it decreased to $360000 \mathrm{~m}^{3}$ year $^{-1}$ due to a series of slightly negative mass balances. However, despite favourable mass balances for the years 1981-84, the 1981-91 period shows high net loss trough melting of $600000 \mathrm{~m}^{3}$ year ${ }^{-1}$. The southern exposure, the decreasing area of the glacier and its shallow vertical extent cause a rapid retreat of the glacier since 1981. As a result, during the 1981-91 decade, with a net melt rate of $90 \mathrm{~cm}$ w.e.year ${ }^{-1}$, the glacier had a specific melt rate five times higher than during the 1850-1906 period (17 cm w.e. year $\left.^{-1}\right)$. It seems that the glacier, reduced in size, is more sensitive to high summer air temperature.

\section{CONCLUSION}

For the first time in France, thanks to valuable old documents, volumetric variation of a small glacier has been quantified over a period of one and a half centuries. The loss of ice is quite remarkable: the glacier volume in 1991,
$16 \times 10^{6} \mathrm{~m}^{3}$, is only $20 \%$ of that in 1850 or $25 \%$ of that in 1906. The tongue retreated more than $1 \mathrm{~km}$, and the surface area shrank from 1.6 to $0.5 \mathrm{~km}^{2}$. If the climate trend observed during the last decade (1981-91) continues, we expect a short remaining lifetime for Glacier de Sarennes: more or less half a century.

\section{REFERENGES}

Berger, F. 1992. Étude des forêts à fonction de protection du Département de la Savoie. Nogent sur Vernisson, École Nationale des Ingénieurs des Travaux des Eaux et Forêts (ENITEF). (Mémoire $3^{\text {ième }}$ année.)

Cherrey, M. 1951. Observations d’octobre 1949 à octobre 1950 du glacier de Sarennes. Mémoires et Travaux de la Section de Glaciologie. Grenoble, Société Hydrotechnique de France, 3-10. (Numéro spécial A.)

Crécy, L. de. 1963. Le glacier de Sarennes et le climat grenoblois. Annales de lEcole Nationale des Eaux et des Forêts et de la Station de Recherches et Expériences, 20 (3), 345-370.

Flusin, G., C. Jacob and J. Offner. 1909. Études glaciaires, géographiques et botaniques dans le massif des Grandes Rousses: rapport des campagnes de 1905 et 1906. Études glaciologiques. Vol. l. Paris, Ministère de l'Agriculture. Direction de l'Hydraulique, Service de l'Études des Grands Forces Hydrauliques (Région des Alpes), 33-112.

Funk, M., H. Bösch and F. Valla. 1993. Mesures desépaisseurs de glace parla méthode radar au glacier de Sarennes. Grenoble, Centre d'Étude de Machinisme Agricole, du Génie Rural, des Eaux et des Forêts. CEMAGREFNivologie.

Garavel, L. 1955. Comportement glaciaire et fluctuations climatiques, glacier de Sarennes. Rev. Forest. Française, 7(1), 9-26.

Girard, G. 1993. Étude photogrammétrique du glacier de Sarennes entre 1975 et 1991. (Mémoire de maîtrise, Université de Chambéry. Section Montagne.

Martin, S. 1978. Analyse et reconstitution de la série des bilans annuels du Glacier de Sarennes, sa relation avec les fluctuations du niveau de trois glaciers du Massif du Mont-Blanc (Bossons, Argentière, Mer de Glace). z. Gletscherkd. Glazialgeol., 13(1-2), 1977, 127-153.

Piedallu, C. 1995. Évaluation du stade "Petit Age de Glacier" du glacier de Sarennes. Saint-Martin-d'Hères, CEMAGREF. Division Nivologie. (Rapport interne.)

Valla, F. 1982. Bilan du glacier de Sarennes, $34^{\text {ième }}$ année d’observation. Compte rendu de la Société Hydrotechnique de France, $34^{i e ̀ m e}$ journées de Glaciologie, février 1982. Grenoble, Société Hydrotechnique de France.

Valla, F. 1989. Forty years of mass-balance observations on Glacier de Sarennes, French Alps. Ann. Glaciol., 13, 269-272. 